\title{
Inheritance of Rust Resistance in Groundnut (Arachis hypogaea L.)
}

\author{
Laxmi C. Patil $^{1 *}$, S.M. Supriya ${ }^{2}$ and P.V. Kenchanagoudar ${ }^{1}$ \\ ${ }^{1}$ National seed Project, UAS, Dharwad, Karnataka, India \\ ${ }^{2}$ Department of Genetics and Plant Breeding, UAS, Dharwad, Karnataka, India \\ *Corresponding author
}

\begin{abstract}
A B S T R A C T

\begin{tabular}{|l|}
\hline Ke y w o r d s \\
$\begin{array}{l}\text { Inheritance, Rust, } \\
\text { Resistance and } \\
\text { Groundnut }\end{array}$ \\
\hline Article Info \\
\hline $\begin{array}{l}\text { Accepted: } \\
\text { 12 August } 2018 \\
\text { Available Online: } \\
\text { 10 September 2018 }\end{array}$ \\
\hline
\end{tabular}

Rust caused by Puccinia arachidis Speg. is the most important disease on Groundnut worldwide. Limited information about nature of inheritance of rust resistance is available to peanut breeders. The investigation was undertaken to determine the mode of genetic inheritance of rust resistance in two $\mathrm{F}_{2}$ populations of groundnut. The crosses were generated by crossing resistant genotypes viz., GPBD5 and ICGV86699 with susceptible genotype TG76. The parents, $F_{1}$ 's and $F_{2}$ populations were evaluated for rust resistance under field conditions by following spreader row technique and spraying uredinospore suspension at 30 and 40 DAS. The disease scoring was recorded using 0-9 scale. Resistance of $F_{1}$ 's to rust in both crosses indicated that resistance was dominant over resistance. Further $F_{1}$ 's were selfed to generate $F_{2}$ populations, where resistance segregated in a ratio of $1 \mathrm{R}: 3 \mathrm{~S}$, with non-significant chi-square values at $5 \%$ level indicating that rust resistance in groundnut is determined by a single recessive gene. This information will be relevant for the implementation of breeding programmes focused on the development of cultivars/hybrids carrying genetic resistance to rust.
\end{abstract}

\section{Introduction}

Peanut (Arachis hypogaea L.), an annual legume grown in more than 100 countries, is widely used as an edible oilseed crop because of its high oil content (36-54\% on dry matter basis) and as a direct source of human food as it contains easily digestible protein (12-36\%) in its seeds. The low productivity of the crop in India is ascribed to many biotic and abiotic stresses. Rust caused by Puccinia arachidis has become a serious problem in major groundnut growing regions of Southern India. Since decade, disease is being observed regularly during Kharif seasons and under severe conditions disease is found infecting whole plant leading to sever defoliation. Cultivated groundnut varieties, especially those belonging to Spanish bunch types are highly susceptible to foliar diseases namely, rust caused by Puccinia arachidis Speg. and late leaf spot (LLS) caused by Phaeoisariopsis personata (Berk. \& Curt.) Van Arx. (McDonald et al., 1985; Subrahmanyam et al., 1985). The yield loss due to the co-occurrence of rust and LLS can go up to $70 \%$ in India when fungicides are not applied (Subrahmanyam et al., 1984; Subrahmanyam et al., 1985). Considerable efforts to breed for rust resistant cultivars have been made 
through conventional breeding approaches; however, the success has been limited due to narrow genetic base, low level of resistance, long duration, low productivity (Subrahamanyam et al., 1993), and undesirable pod features. Selection of desirable recombinants is difficult due to interference among the foliar diseases and complex inheritance pattern (Bromfield and Bailey, 1972; Tiwari et al., 1984; Paramasivam et al., 1990). However, a few improved genotypes showed foliar disease resistance along with desirable pod and kernel features (Gowda et al., 2002; Nadaf et al., 2009; Gajjar et al., 2014). Use of wild diploids, which are foliar disease resistant, in the breeding programme through synthetics is known to broaden the genetic base in many crops including groundnut (Mallikarjuna et al., 2011; Varshakumari et al., 2014).

Fungicide application is an effective method to control the disease, but the production cost would be high and also hazardous to environment (Mallikarjuna et al., 2011; Varshakumari et al., 2014). Sources of resistance to rust and LLS have been identified in some genotypes of cultivated groundnuts. Development of disease resistant varieties is the cheapest method of disease control. Thus, knowledge of inheritance is very useful for formulation of breeding strategy to introgression of genes into the agronomically superior cultivars.

Although earlier studies reported that resistance is naturally complex and polygenic and probably governed by several recessive genes (Green and Wyne, 1986, Motagi, 2001 and Dwivedi et al., 2002). Study on the inheritance of rust on groundnut was also performed by earlier workers (Motagi et al., 2001; Nevill, 1980). The present study was conducted to understand the mode of inheritance of resistance to rust in $F_{2}$ generation of two crosses.

\section{Materials and Methods}

The experimental material comprising of $2 \mathrm{~F}_{2}$ populations viz., TG76 $\times$ GPBD5 and TG76 $\times$ ICGV-86699. They were grown at NSP, MARS, UAS, Dharwad, India during the rainy season of 2015 in simple lattice design with a row length of $3 \mathrm{mt}$ and spacing of $45 \times 15 \mathrm{~cm}$.

\section{Field screening of groundnut for rust}

The $F_{2}$ populations were screened for rust by creating artificial epiphytic conditions. Rust inoculums were manintained on TMV2 and JL24 (susceptible checks) plants. The artificial epiphytotic conditions were created using 'Spreader Row Technique' (Subramanyam et al., 1995) in which disease spreader plants were planted at every $20^{\text {th }}$ row in experimental plot. The infected leaves from the heavily infected plants were collected from field and soaked in water for $30 \mathrm{~min}$, rust uredinospores were released by rubbing the infected leaves in the water. The inoculums containing 20,000 to 70,000 spores $/ \mathrm{ml}$ water was mixed with Tween 80 as mild surfactant. Such spore suspension prepared was sprayed on all the genotypes at 30 and 45 days after sowing around 4 to 5 PM using a Knapsack sprayer for a week. Observations on disease incidence were recorded at 10 days interval from 70 DAS up to 90 DAS for identification of precise resistant genotypes using modified 0-9 scale (Subbarao et al., 1990). Three randomly selected plants were counted for percentage defoliation. Disease severity observations were recorded on three randomly chosen plants from each $F_{2}$ genotype (Fig. 1).

\section{Results and Discussion}

The $F_{2}$ plants showing that susceptibility is dominant over resistance in both the crosses. The $F_{2}$ segregation had a good fit to a phenotypic ratio of 3 susceptible: 1 resistance plants in both the crosses. 
Fig.1 The modified 9-point scale for field evaluation of rust of groundnut

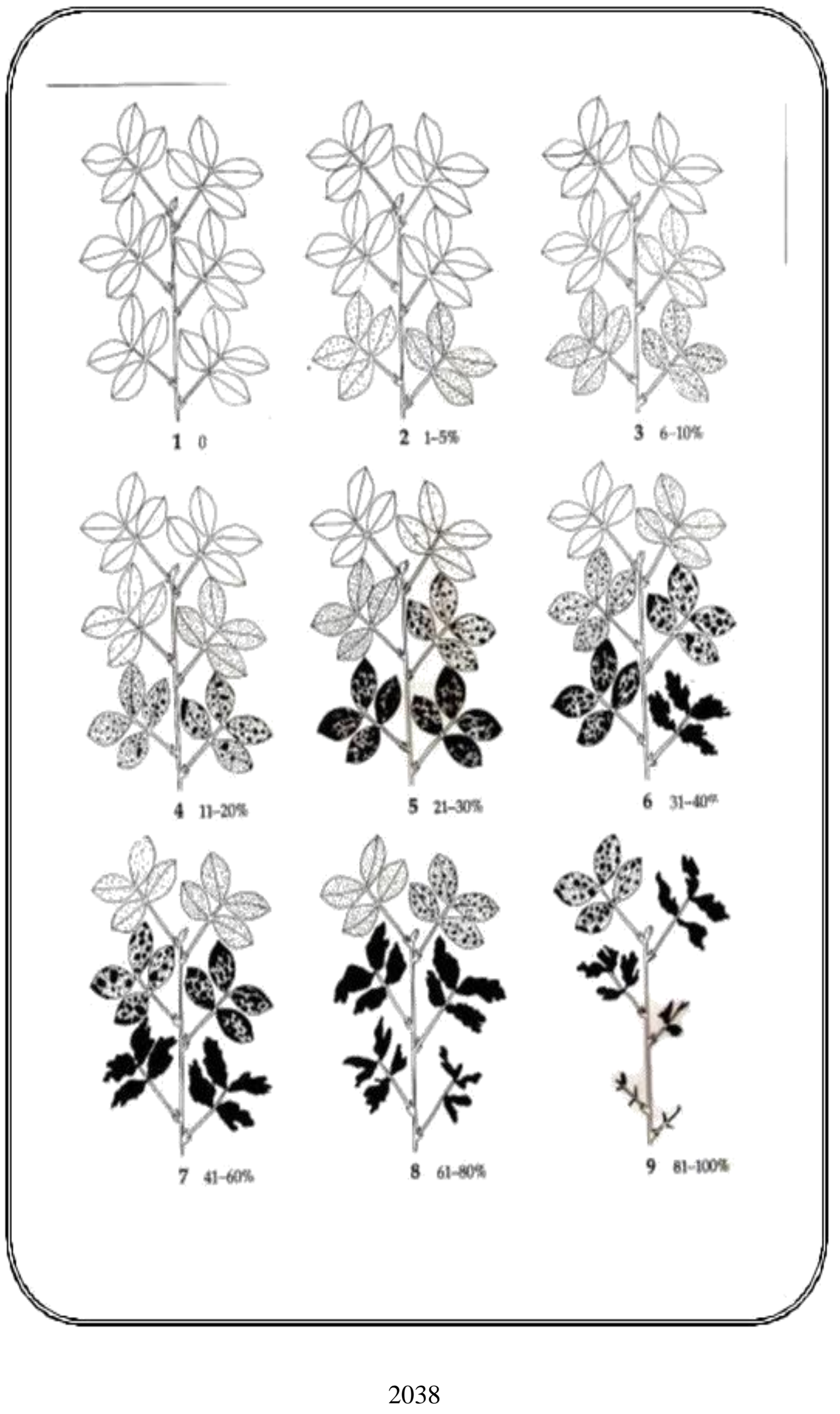


Table.1 Inheritance of rust resistance in two $\mathrm{F}_{2}$ population of groundnut

\begin{tabular}{|c|c|c|c|c|c|c|c|c|c|}
\hline \multirow[t]{2}{*}{ Cross } & \multirow{2}{*}{$\begin{array}{c}F_{1} \\
\text { reaction }\end{array}$} & \multirow{2}{*}{$\begin{array}{l}\text { Screening } \\
\text { conditions }\end{array}$} & \multirow{2}{*}{$\begin{array}{c}\text { Total } \\
\text { plants } \\
\text { screened }\end{array}$} & \multicolumn{2}{|c|}{ Observed frequency } & \multirow[t]{2}{*}{ Ratio } & \multirow{2}{*}{$\begin{array}{l}\text { Calculated } \\
\text { Chi- } \\
\text { square } \\
\text { value }\end{array}$} & \multirow{2}{*}{$\begin{array}{l}\text { Table } \\
\text { Chi- } \\
\text { square } \\
\text { value }\end{array}$} & \multirow{2}{*}{$\begin{array}{c}\text { Significance } \\
\text { level }\end{array}$} \\
\hline & & & & $\begin{array}{c}\text { Resistant } \\
\text { plants } \\
(<10 \% \\
\text { infection })\end{array}$ & $\begin{array}{c}\text { Susceptible } \\
\text { plants } \\
(>10 \% \\
\text { infection) }\end{array}$ & & & & \\
\hline $\begin{array}{l}\text { TG76x } \\
\text { ICGV86699 }\end{array}$ & $\mathrm{R}$ & Natural & 270 & 68 & 202 & $1: 3$ & 0.01 & 3.847 & $\mathrm{NS}(0.05)$ \\
\hline TG76×GPBD5 & $\mathrm{R}$ & Natural & 107 & 28 & 79 & $1: 3$ & 0.08 & 3.847 & $\mathrm{NS}(0.05)$ \\
\hline
\end{tabular}

The results of genotypic constitution of the $\mathrm{F}_{2}$ segregation ratios are presented in the Table 1. From these results it is clear that resistance to rust is governed by single recessive gene, where susceptibility being dominant over resistance (Dwivedi et al., 2002). The $\mathrm{F}_{1}$ generation of all the crosses also showed resistance reaction to rust. Resistance to rust disease is governed by single recessive genes (Gowda et al., 2002).

Rust is the major diseases that affect yield and other quality parameters. The disease can be controlled by chemical sprays but it has drastic effect on the environment and various useful micro-organisms, so an alternative method is to develop genetically resistant plants for these diseases. The results of this study showed that the reactions of $F_{2}$ population against rust under field conditions can be classified into modified 0-9 scale. It provides clear evidence about resistance to rust disease is governed by single recessive gene. This information can be relevant for plant pathologist or the implementation of breeding programs focused on development of new cultivar carrying genetic resistance to rust.

\section{References}

Bromfield, K. and Bailey, W., 1972, Inheritance of resistance to Puccinia arachidis in peanut. Phytopathology, 62: 748 .
Dwivedi, S. L., Pande, S., Rao, J. N. and Nigam, S. N. 2002. Components of resistance to late leaf spot and rust among interspecific derivatives and their significance in a foliar disease resistance breeding in groundnut (Arachis hypogaea L.), Euphytica. 125: 81-88.

Gowda, M. V. C., Motagi, B. N., Naidu, G. K., Diddimani, S. B. and Sheshagiri, R. 2002. GPBD 4: A Spanish bunch groundnut genotype resistant to rust and late leaf spot. International Arachis Newsletter. 22: 29-32.

Gowda, M. V. C., Motagi, B. N., Naidu, G. K., Diddimani, S. B. and Sheshagiri, R., 2002. GPBD 4: A spanish bunch groundnut genotype resistant to rust and late leaf spot. Int. Arachis Newslet., 22: 29-32

Green, C. C. and Wynne, J. C., 1986, Diallel and generation means analyses for the components of resistance to Cercospora arachidicola in peanut. Theor. Appl. Genet., 73: 228-235.

Mallikarjuna, N., Senthilvel, S. and Hoisington, D., 2011, Development of new sources of tetraploid Arachis to broaden the genetic base of cultivated groundnut. Genet. Resour. Crop Evol., 58(6): 889-907.

McDonald, D., Subrahmanyam, P., Gibbons, R. W. and Smith, D. H., 1985, Early and late leaf spots of groundnut. Information Bulletin No. 21, 
International Crops Research Institute for the Semi Arid Tropics (ICRISAT), Patancheru, A. P., India, pp. 1-19.

Motagi 2001. Genetic analysis of resistance to late leaf spot and rust vis-à-vis productivity in groundnut (Arachis hypogaea L.). Dissertation, University of Agricultural Sciences, Dharwad, India.

Nevill, D. J. 1980. October. Studies of resistance to foliar pathogens. In Proceedings of the international groundnut workshop, ICRISAT, Patancheru, Andhra Pradesh, India. pp. 199-202.

Nevill, D., 1981, Components of resistance to Cercospora arachidicola and Cercosporidium personatum in groundnuts. Ann. Appl. Biol., 99(1): 7786.

Paramasivam, K., Jayasekhar, M., Rajasekharan, R. and Veerabadhiran, P., 1990, Inheritance of rust resistance in groundnut (Arachis hypogaea L.). Madras Agric. J., 77(1): 50-52.

Subbarao, P. V., Subramanyam, P. and Reddy, P. M., 1990, A modified nine points diseases scale for assessment of rust and late leaf spot of groundnut. Proc. Second International Congress of French Phytopathological Society, 2830 November 1990, Montpellier, France, $\mathrm{p} 25$.
Subrahmanyam, P., Bosc, J., Hassane, H., Smith, D., Mounkaila, A., Ndunguru, B. and Sankara, P., 1992, Groundnut diseases in Niger and Burkina Faso. Oleagineux (Paris), 47(3): 119-133.

Subrahmanyam, P., McDonald, D., Waliar, F., Reddy, L. J., Nigam, S. N., Gibbons, R. W., Rao, V. R., Singh, A. K., Pande, S., Reddy, P. M. and Rao, P. V. S., 1995, Screening methods and sources of resistance to rust and late leaf spot of groundnut. Information Bulletin, 47, ICRISAT, Patancheru, Andhra Pradesh, p.33.

Subrahmanyam, P., Rao, V. R., McDonald, D., Moss, J. P. and Gibbons, R. W. 1989. Origins of resistance to rust and late leaf spot in peanut (Arachis hypogaea L.). Economic Botany. 43: 444-455.

Tiwari, S. P., Ghewande, M. P. and Mishra, D. P., 1984, Inheritance of resistance to rust and late leaf spot in groundnut (Arachis hypogaea L.). J. Cytol. Genet, 19: 97- 101.

Varshakumari. 2013, Introgression of foliar disease resistance using synthetic amphidiploids and identification of associated QTLs in groundnut (Arachis hypogaea L.). Ph. D. Thesis, Univ. Agric. Sci, Dharwad, India. Patancheru, Andhra Pradesh, India. pp. 199-202.

\section{How to cite this article:}

Laxmi C. Patil, S.M. Supriya and Kenchanagoudar, P.V. 2018. Inheritance of Rust Resistance in Groundnut (Arachis hypogaea L.). Int.J.Curr.Microbiol.App.Sci. 7(09): 2036-2040. doi: https://doi.org/10.20546/ijcmas.2018.709.247 